\title{
Plants, people and culture in the villages of Oikull and Ibobang, Republic of Palau
}

\author{
Ann Hillmann Kitalong ${ }^{1,3}$, Michael J. Balick', Faustina Rehuher', Meked Besebes', \\ Sholeh Hanser ${ }^{1,3}$, Kiblas Soaladaob ${ }^{1}$, Gemma Ngirchobong ${ }^{1,3}$, Flora Wasisang', Wayne \\ Law $^{2}$, Roberta Lee ${ }^{4}$, Van Ray Tadeo, ${ }^{1}$ Clarence Kitalong ${ }^{3}$ and Christopher Kitalong ${ }^{1,3}$ \\ 1. Belau National Museum, Republic of Palau \\ 2. The New York Botanical Garden, Institute of Economic Botany, USA \\ 3. The Environment, Inc., Republic of Palau \\ 4. Beth Israel Medical Center, New York City, USA
}

\section{Introduction}

Ethnobotany is the investigation of the interaction between plants, people and culture (Jones 1941; Arvigo and Balick 1998; Balick and Cox 2005). The body of knowledge and practices developed and maintained by people interacting with their natural environment over time is known as traditional knowledge. This can include information on plants used for food, shelter, medicine, tools, arts and crafts, aesthetic beauty and spiritual purposes. Due to its dynamic nature, traditional knowledge is difficult to quantify (Lee et al. 2001). The loss of traditional practices is a threat to biodiversity globally (Balick and Cox 2005) and to Palau's communities (Palau National Biodiversity Strategy and Action Plan 2004). Lee and colleagues (2001) found that in Pohnpei traditional knowledge had significantly eroded within three generations for such daily tasks as planting taro, fermenting breadfruit, using plants for fish poison, making canoes and catching turtles. To counteract this threat in Micronesia, the Biodiversity and Human Health Project was initiated in Pohnpei in 1997 (Balick 2009), and as of 2007, has been ongoing in Palau and Kosrae. The goal of this project is to establish a link between ecosystems and human health.

Traditional medicines have been used for thousands of years worldwide. It is probable some of the canoe plants that arrived with Palau's early settlers 3000-4000 years ago were transported due to their medicinal properties. Healers still refer to the ca. 1700-year-old Chinese text Materia Medica, attributed to Shen Nong, that describes the medicinal properties of 252 plant species. India has made use of more than 7500 plants (Kapoor 1990; Mukherjee and Wahile 2006). The World Health Organisation estimates that $80 \%$ of the world's inhabitants continue 
to rely significantly on traditional medicine systems for their primary health care. The remaining $20 \%$ of the population depends on pharmaceutical medicines - and one in four of these contain plant extracts or active chemicals derived from 90 different plant species (Farnsworth et al. 1985). Although Western health care is available to varying degrees in many parts of the world, including the Pacific, traditional medicine is still widely practised in Oceania (Whistler 1992, 1996; Balick 2009). These traditional medical systems employ native tropical island plants, some of which are found nowhere else in the world. Health care based on traditional practices that are consistent with international standards of quality control is now being advocated in the worldwide medical community, including Micronesia (Lee 2009).

Ethnobotanical studies in the Palauan archipelago in western Micronesia have focused on the medicinal uses of plants (Okabe 1941; Black 1968; Salsedo 1970; Salsedo and Smith 1987; Defilipps et al. 1988; Friend and Tabak 1995; Palau Society of Historians 2000, 2001; Machiko 2002; Del Rosario and Esquerra 2003) and construction of the bai, the traditional men's meeting house (Telmetang 1993). The medicinal studies in Palau have documented more than 80 plant species with more than 235 medical uses, with the most recent study showing activity against the Hepatitis C virus for several native Palauan plant species (Kitalong 2007). Palau's early ethnohistorical sources (Krämer 1917, 1919, 1929) address plant use in Palauans' daily lives. These early studies lack records crediting the informants and do not detail the step-by-step processes for the use of many species. There may be several reasons for this, including the lack of translators, a society that was more protective of its knowledge, and a lack of understanding the value and significance of this information for future studies.

Previous studies of Palau's flora include Kanehira (1933) and Fosberg and his colleagues' extensive 45 years of floristic surveys and systematics (Fosberg 1946, 1947, 1957, 1960; Fosberg and Sachet 1975a, 1975b, 1977, 1979, 1980a, 1980b, 1981, 1984, 1987, 1991; Fosberg et al. 1979, 1982, 1987, 1993; Fosberg et al. 1980; Fosberg and Raulerson 1990). Palau's other vegetation studies consist of descriptions of wetland communities including mangrove forests (Stemmermann 1981), a comprehensive vegetation survey (Cole et al. 1987), a rapid ecological study of the Ngeremeduu Bay Drainage (Canfield et al. 1992) and a botanical reconnaissance of Babeldaob (Raulerson et al. 1997). Palau's forests have been systematically inventoried (Donnegan et al. 2007) and important forest areas, long-term vegetation trends and species diversity were studied (Hillmann Kitalong and Holm 2004; Costion and Kitalong 2006; Hillmann Kitalong 2008; Hillmann Kitalong et al. 2009).

Palaeoenvironmental studies using charcoal and palaeobotanical remains are reconstructing Palau's ancient landscape (Athens and Ward 2001, 2002, 2005). Palau's lowland forests cover $87 \%$ of the land, of which $75 \%$ is native forest. Prehistoric earthworks cover a minimum of $20 \%$ of Babeldaob and impact an area double that size due to the intensive erosion resulting from their construction (Liston 2009). This erosion may explain the alluvial soils of the lowlands (Athens and Ward 2005; Liston and Tuggle 2006; Masse et al. 2006). Integration of ethnobotanical and archaeological studies provides a better understanding of long-term changes in plant communities and their impact on human culture over time.

This ethnobotanical study was initiated at the Belau National Museum (BNM) in partnership with the New York Botanical Garden and the National Tropical Botanical Garden. The goal of the program is to document the traditional knowledge and practices regarding the use of plants through life's passage from birth to death. Presented here is a preliminary ethnobotanical study of the villages of Oikull and Ibobang on Babeldaob. 


\section{Materials and methods}

The Republic of Palau, located within latitudes $08^{\circ} 12^{\prime}$ to $2^{\circ} 48^{\prime}$ and longitudes $131^{\circ} 07^{\prime}$ to $134^{\circ} 44^{\prime}$, is the westernmost archipelago of the Caroline Islands in Micronesia (Figure 1). The study sites are located on Babeldaob, Palau's largest island, in the village of Oikull in Airai state, and in the village of Ibobang in Ngatpang state. Oikull, in southeast Babeldaob, has volcanic, limestone and mangrove forests and freshwater wetlands and grasslands. Due to Oikull's unique transitional location on both volcanic and limestone soils, it contains a diverse assemblage of plants. Although with a similar habitat, Ibobang, on the shores of Ngaremeduu Bay in southwest Babeldaob, is on volcanic soils so does not have the limestone forest habitat of Oikull.

Oikull and Ibobang were chosen as study sites by the Belau National Museum Board based on a number of considerations, including local interest, accessibility, the level of cultural knowledge and the presence of plant diversity. These two villages are considered 'proof of principle' sites, where development of methodologies and training for studies elsewhere in Palau will be undertaken.

Earthworks complexes, pottery scatters and abandoned stonework villages connected by a network of stone paths attest to the fact that Oikull is an ancient village area that was once densely populated. Many people can trace their roots to Oikull as it plays a significant role in Palau's migration stories. The original settlers came from Metuker Rikull, a small rock island near Oikull where fishermen were famous for their shark-hunting skills. ${ }^{1}$ Today few residents live in the village due to lack of adequate roads providing access to schools. The villagers have moved to locations that are more convenient and closer to schools although they would like

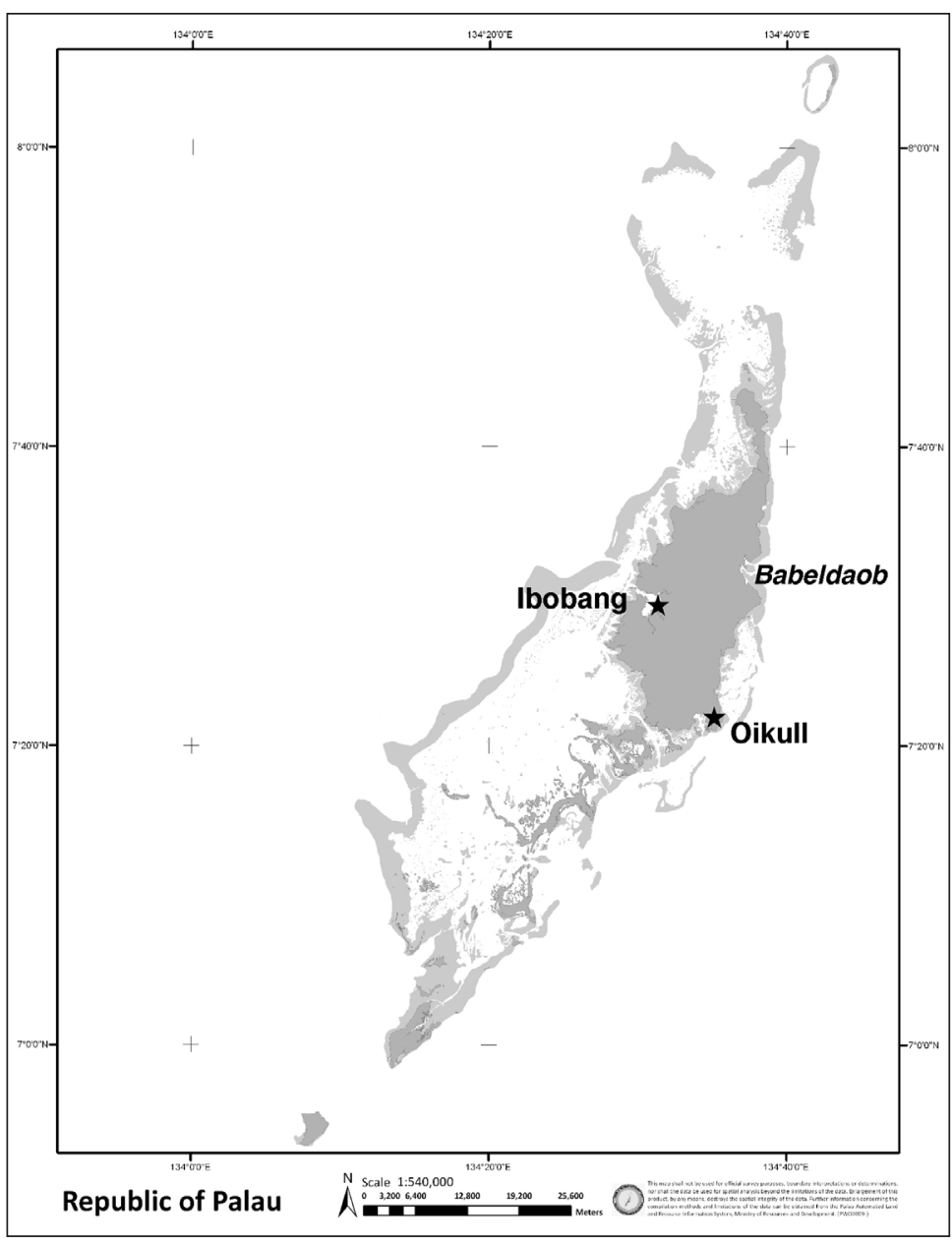

Figure 1. Study sites on Babeldaob, Republic of Palau (Source: PALARIS). 
to move back to Oikull. Oikull was chosen for study due to the large number of community members who originated from this village with potential knowledge of traditional skills.

Ibobang, a village established in the recent historic era, is the centre of the Modekngei religion whose followers believe in the ancient gods and follow customary rituals and healing practices (Machiko 2002). Ibobang was donated by the Inglii clan to the founder of the Modekngei religion, Tamadad, who came from Choll, a village on Babeldaob's northeast coast. Ibobang was chosen for the study due to the large number of community members who are active practitioners of traditional skills.

A preliminary meeting was held with village elders at the Belau National Museum to explain the project's purpose and obtain informed consent. After community meetings in the two states, informal interviews were set up with those villagers recommended by the elders as knowledgeable about the use of plants. Interviews began by obtaining background information about the individuals, including age, place of birth, time in villages, migrations between villages and the activities they participated in or observed during childhood and adulthood. Specific questions focused on recreation, food preparation, medicine for primary care, building and special customary practices. Several interview approaches were used, although the preferred method was to walk in the informant's neighbourhood forest as the informant indicated specific plants for a given purpose. Replicate voucher specimens could then be collected on site.

Some elders preferred that plants be brought to them for verification, while others came to the BNM herbarium for interviews and voucher species were presented for authentication. The interviewer would ask whether a given species had a use, but did not state a use or ask for confirmation of a use for a given plant. Most interviews were carried out in one session, although time constraints required some informants to have several interviews. Both individual and group interviews were conducted. In the latter interviews, it is difficult to attribute information to a single person, so information was accredited to the group. Attributing information to specific people documents ownership of their intellectual property, their rights for its use and any benefits derived from this knowledge under the principles of the Convention of Biological Diversity. It also establishes the concept of prior art and prior knowledge to identify the source of the information.

During field interviews, voucher specimens were collected in a field press and the site was georeferenced using a Garmin GPS unit. Specimens were processed in the BNM herbarium within 24 hours of collection and results were entered into the herbarium database. GPS points were downloaded, analysed and mapped using Arcview@ software. Transcribed field notes provided data for voucher specimen labels that list the name(s) of the informant(s), the identification of taxa, the description of the plant, the plant habitat and associated plants, and the documented uses provided by the informant(s). The voucher specimens were distributed to regional and international herbaria for specialists to confirm their identification. The informants reviewed and modified interview summaries. Below, the names of individuals who contributed information appear in parenthesis following specific use data. The information collected in the project was shared with the village communities in a series of PowerPoint presentations.

\section{Plant uses}

A total of 43 interviews were conducted: 27 in Oikull (17 women, 10 men) and 16 in Ibobang (nine women, seven men). In Oikull, interviewees provided 448 uses for 170 plants, while in Ibobang, informants provided 271 uses for 127 plants. Medicine, food and construction were the top three categories of recorded plant usage. Other categories included in the study were menstruation and childbirth, recreation, ropes and ties, firewood, cleaning, fishing and hunting. 
A list of 28 categories of uses was derived from the information given by the interviewees during this study (Appendix 1). The frequency of reported plant uses divided into major use categories is listed in Table 1 . These plants are commonly found throughout Palau's urban landscape.

Table 1. Frequency of reported plant uses by major categories.

\begin{tabular}{lccc}
\hline Major categories & Total & 0ikull $(\mathbf{n}=\mathbf{2 7})$ & Ibobang $(\mathbf{n}=\mathbf{1 6})$ \\
\hline Medicine & 248 & 123 & 125 \\
Food & 198 & 132 & 66 \\
Construction & 104 & 54 & 50 \\
Toys & 43 & 27 & 16 \\
Tools & 28 & 20 & 8 \\
Cleaning & 26 & 15 & 11 \\
Rope & 22 & 14 & 8 \\
Fishing & 21 & 14 & 20 \\
Canoe Building & 18 & 8 & 11 \\
Total & $\mathbf{7 0 8}$ & $\mathbf{4 0 7}$ & $\mathbf{3 1 5}$ \\
\hline
\end{tabular}

The main categories of usage and the number of plant species used according to the male (Table 2) and female informants (Table 3) indicated that men are more knowledgeable about plants used for construction, firewood, fishing, and fashioning tools, canoes and rope. Women provided more information about plants used for food preparation and medicinal plants used in childbirth. Both men and women are knowledgeable about plants used for food, toys and general-purpose, primary-care medicines.

First menstruation

In one clan, a ritualistic cleansing using Pandanus tectorius (ongor), Areca catechu (betel nut, buuch) and Citrus maxima (pomelo, malchianged) is performed after the first menstruation (F. Wasisang). Another clan in Ibobang uses Cymbopogon citratus (lemongrass, keskus), Citrus sp. (cheluchau), Decaspermum fruticosum (kertaku), Eurya japonica (cheskiik) and roasted Cocos nucifera (coconut, lius) for the cleansing (G. Emesiochel).

\section{Childbirth}

After giving birth to their first child, women undergo a complex bathing process (omengat) that lasts from four to 10 days. The ritual's purpose is to heal the new mother and celebrate her first child. At least two months of preparation are needed for this event. Activities include constructing the bathing and steam hut, gathering firewood, gathering herbs, preparing ginger and coconut oil for the bath, preparing food, and making the traditional skirt and accessories for the mother for the last day of celebration. This ceremony culminates in a final bath and display of the young mother in her traditional dress for the father's family. The mother's family prepares a banquet of food, the father's family provides money, and a life-long bond is then established.

A variety of herbs is used in the ritual to energise and heal the new mother. There is no single prescribed set of plants used in the first bath ceremony and many clans have their own particular formula. Twenty plant species were listed as being used during the hot-bath process by the female interviewees from Oikull (16 species) and Ibobang (13 species) (Table 4). The most commonly listed plant $(\mathrm{n}=11)$ is Curcuma longa (turmeric, kesol), with the remaining plants described by at the most only two informants each. 
Table 2. Main plant uses and number of plant species given by the men interviewed.

\begin{tabular}{lccc}
\hline Use category & Number of species & Oikull $(\mathbf{n}=\mathbf{1 0})$ & Ibobang $(\mathbf{n}=\mathbf{7})$ \\
\hline Food & 25 & 17 & 8 \\
Medicine & 67 & 41 & 26 \\
Construction & 81 & 38 & 43 \\
Toys & 23 & 17 & 6 \\
Fishing & 19 & 9 & 10 \\
Canoe building & 10 & 4 & 6 \\
Rope or tie & 16 & 12 & 4 \\
Total & $\mathbf{2 4 1}$ & $\mathbf{1 3 8}$ & $\mathbf{1 0 3}$ \\
\hline
\end{tabular}

Table 3. Main plant uses and number of plant species given by the women interviewed.

\begin{tabular}{lccc}
\hline Use category & Number of species & Oikull $(\mathbf{n}=\mathbf{1 7})$ & Ibobang $(\mathbf{n}=\mathbf{9})$ \\
\hline Food & 26 & 17 & 9 \\
Medicine & 95 & 45 & 50 \\
Construction & 6 & 1 & 5 \\
Toys & 12 & 6 & 6 \\
Fishing & 6 & 4 & 2 \\
Food wrap & 12 & 5 & 7 \\
Total & $\mathbf{1 5 7}$ & $\mathbf{7 8}$ & $\mathbf{7 9}$ \\
\hline
\end{tabular}

\section{Recreation}

Men and women, mostly elders, described different types of recreational activities in which they participated from an early age. Some of these activities employing plant products are practised by children today. A total of 22 plant species were used for childhood games and recreation according to the interviewees. Seven plant species were frequently described by the interviewees to make blowguns, spin wheels, balls, jump rope, bean bags and puzzles (Table 5). The three most frequently described plant species are Heterospathe elata var. palauensis (demailei) used to fashion blowgun bullets, Schizostachyum lima (lild) used to make the blowgun spears, and Merremia peltata (kebeas) used for jump ropes. Both Flagellaria indica (bangernguis) and Leucaena leucocephala (telentund) were made into bean bags. Balls and spin wheels were created from Cocos nucifera and puzzles were assembled from Xylocarpus granatum (meduulokebong).

\section{Traditional food and food preparation}

Thirty-two plant species were recorded as sources of food and useful in food preparation with 27 species being classed as important foods. As this list focused on the elders' favoured traditional food types, the actual number of food plants is under-represented. Documentation of plants used as traditional foodstuff will be expanded on in future interviews.

The most frequently mentioned plant species described as a source of traditional food are two types of taro, Colocasia escuelenta (wet taro, dait) and Cyrtosperma chamissonis (giant swamp taro, prak), Manihot esculenta (tapioca, diokang), Cocos nucifera and Inocarpus fagifer (Tahitian chestnut, keam). Tapioca is believed to have been introduced by the Germans in the early 20th century (Mayo 1954). 
Table 4. Plants used in the first-birth bath and ceremony.

\begin{tabular}{|c|c|c|}
\hline Species (Palauan name) & Oikull $(n=17)$ & Ibobang $(n=9)$ \\
\hline Curcuma longa L. (kesol) & 8 & 3 \\
\hline Cocos nucifera L. (lius) & 1 & 2 \\
\hline Cassytha filiformis L. (techellela chull) & 1 & 1 \\
\hline Melastoma malabathricum L. var. mariannum (Naudin) Fosb. and Sach. (matakui) & 1 & 0 \\
\hline Phaleria nisidai Kaneh. (ongael) & 1 & 1 \\
\hline Dianella carolinensis (kobesos) & 1 & 0 \\
\hline Limnophila chinensis (Osb.) Merr. subsp. aromatica (Lam.) (iaml) & 1 & 1 \\
\hline Phyllanthus palauensis Hosok. (dudurs, udoud) & 1 & 0 \\
\hline Melicope denhamii (Seem.) T.G. Hartley (kertub) & 1 & 1 \\
\hline Pandanus tectorius Parkinson ex Du Roi (ongor) & 1 & 1 \\
\hline Cymbopogon citratus (DC. ex Nees) Stapf (keskus) & 1 & 1 \\
\hline Cinnamomum carolinense (ochod) & 1 & 0 \\
\hline Citrus maxima (Burm. ex Rumph.) Merr. (malchianged) & 0 & 2 \\
\hline Cananga odorata (Lam.) Hook. F. and Thomson (irang irang) & 1 & 0 \\
\hline Syzygium samarangense (Blume) Merr. and Perry (rebotel) & 2 & 0 \\
\hline Millettia pinnata (L.) Panigrahi (kisaks) & 1 & 1 \\
\hline Eurya japonica Thunb. var. nitida (kertaku) & 2 & 0 \\
\hline Eugenia reinwardtiana (Blume) DC. (kesiil) & 0 & 1 \\
\hline Pouteria obovata (R. Brown) Baehni (chelangel) & 0 & 2 \\
\hline Derris trifoliata Lour. (kemokem) & 0 & 1 \\
\hline Total & 25 & 18 \\
\hline
\end{tabular}

Table 5. The most frequently named plants with recreational uses.

\begin{tabular}{|c|c|c|c|c|}
\hline Species (Palauan name) & Use & $\begin{array}{l}\text { Total interviewed } \\
\qquad(n=43)\end{array}$ & $\begin{array}{l}\text { Oikull } \\
(n=27)\end{array}$ & $\begin{array}{c}\text { Ibobang } \\
(n=16)\end{array}$ \\
\hline Heterospathe elata Scheff. var. palauensis (Becc.) (demailei) & Blowgun bullet & 7 & 3 & 4 \\
\hline Schizostachyum lima Merr. (lild) & Blowgun & 5 & 1 & 4 \\
\hline Cocos nucifera L. (lius) & Spin wheel, balls & 2 & 2 & 2 \\
\hline Merremia peltata (L.) Merr. (kebeas) & Jump rope & 5 & 1 & 4 \\
\hline Flagellaria indica L. (bangernguis) & Bean bags & 2 & 1 & 1 \\
\hline Leucaena leucocephala (Lam.) de Wit (telentund) & Bean bags & 2 & 2 & 0 \\
\hline Xylocarpus granatum Koenig (meduulokebong) & Puzzle & 2 & 1 & 1 \\
\hline Total & & 25 & 11 & 16 \\
\hline
\end{tabular}

The main starch of customary significance is Colocasia escuelenta. The plant is referred to as dait and the cooked corm is referred to as kukau. Traditionally, taro is the most important and most revered (prestige) food and crop in Palau. It is included in all rituals and customs and features prominently in Palau's legends, stories, songs, chants and proverbs. Taro is the most important starch used in Palau's customary exchanges. The cultivation of taro is the main role 
of women and a source of pride for women and their families. The inheritance of taro gardens is through the women (Figure 2).

Both the foliage and the root of the taro plant are used as a food source. Colocasia and Cyrtosperma can be prepared in different ways: the corm can be simply boiled (meliokl), boiled and cooked with coconut milk (cheluit), boiled and ground (belsiich), or ground and mixed with sugar and baked as a dessert. The leaves can be mixed with coconut milk and other ingredients to make a favourite Palauan soup (demok) and the stems can be cooked with sugar for a dessert (chelang).

Traditionally, Palauan food is often boiled, steamed or baked inside a leaf casing. This not only imparts the flavour of the leaf to the food, but also holds the food together during cooking and protects it from exposure to adjacent contaminants such as charcoal or sand. Once cooked, the leaf package is easily portable and can be stored as is. The plants used to wrap food were given as Cordyline fruticosa (sis), Cocos nucifera and Areca catechu.

Taro patch

The majority of Colocasia grows in prepared wetland plots (mesei). Production systems relied on less frequently include damp gardens (dechel) and dryland gardens (sers). Mesei are paddy-like systems with channels and dikes used for water control, to divide the gardens into functional sections indicating the ultimate use of the taro grown, and to isolate plots from diseases. The mesei serve as an agroforest, with various useful trees and shrubs grown on the dikes and perimeter, mainly for food, green manure, medicine and ceremonies.

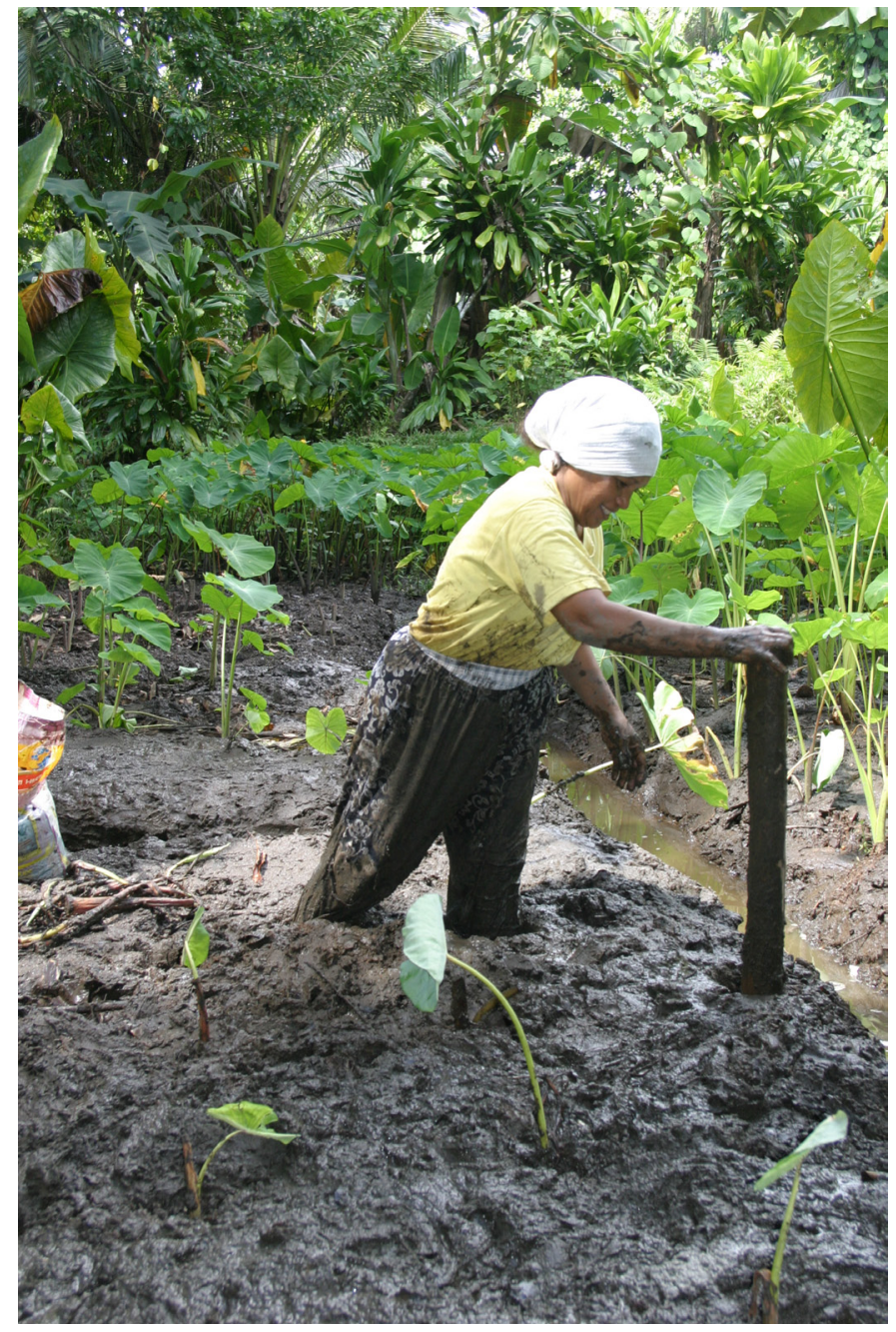

Figure 2. Ellen Adelbai preparing her wetland taro garden (mesei). 
Leaves from many species of trees can be used as green manure for the taro patches, including Osmoxylon oliveri (kesiamel), Musa spp. (banana, tuu), Cocos nucifera, Areca catechu and the large leaves of the giant taro, Cyrtosperma merkusii (prak). In Ngatpang, the women also use Elaeocarpus joga (dekemerir) and Cerbera manghas (chemeridech) as fertiliser (G. Emesiochel). Fertiliser, most commonly green manure, is both placed in the planting hole and spread on the top of the prepared beds as mulch to promote soil fertility.

Taboo food

Dietary taboos in Palau are most often associated with fish and other sea creatures. Papaya or Carica papaya is considered a taboo food during menstruation (F. Wasisang). Women who are either pregnant or breast feeding should avoid pineapple (Ananas comosus, ongor ra Ngebard) because it irritates the baby and gives a bad odour (E. Singeo).

\section{Construction}

A total of 41 species of plants were described as construction materials (Table 2). Metal tools have replaced the traditional shell or stone adzes once used to fell and shape the tree. Tool handles continue to be fashioned from Palauan wood species, including Calophyllum inophyllum (btaches) (C. Kitalong, R. Emesiochel, V.R. Tadeo), Cocos nucifera, Hibiscus tiliaceus (chermall), Macaranga carolinensis (bedel), Rhizophora mucronata (tebechel), Terminalia catappa (miich) and Syzygium samarangense (rebotel) (C. Kitalong).

\section{Structures}

Those plant species most frequently named by the informants as used to build structures are listed in Table 6. Intsia bijuga (dort) is a very heavy and strong hardwood used to build houses (C. Kitalong), house frames (T. Tesei) and flooring (T. Belchal). Stemonorus ammui (ngmui) is used for beams and posts (R. Emesiochel), crossbeams (H. Nabeyama) and flooring (S. Ubedei). Gmelina palawensis (blacheos) is used for posts (S. Ubedei), flooring and walls. Flooring is also constructed from Bruguiera gymnorrhiza (kodenges) (H. Nabeyama), Bambusa vulgaris (bambuu) and Serianthes kanehirae (ukall). Trees used to build the main frame of the house include Lumnitzera littoralis (mekekad) and Calophyllum pelewensis (chesemolech) (S. Ubedei). Lumnitzera littoralis is also used for a structure's posts and the upper house, as is Campnosperma breviopetiolata (kelelacharm) (R. Emesiochel) and Sonneratia alba (urur) (H. Nabeyama). Trees used to construct the frame of a dock and for posts include Rhizophora mucronata and Sonneratia alba (R. Emesiochel, T. Belchal). Ceriops tagal (buit) is also used for construction (C. Kitalong, T. Tesei, R. Alii), to build canoe houses (diangel) (W. Metes), for posts (T. Belchal) and for house frames (H. Nabeyama).

Canoe building

The men interviewed provided information about 10 trees that produce wood suitable for crafting canoes (Table 2). The most common species reported (Table 7) is Serianthes kanehirae (T. Belchal, R. Bausouch, S. Yano, C. Kitalong, R. Emesiochel, H. Nabeyama, S. Ubedei). Other wood taxa for canoe construction are Artocarpus atilis (meduu) (C. Kitalong, S. Ubedei), Artocarpus mariannensis (chebiei) (C. Kitalong, R. Emesiochel), Calophyllum inophyllum (C. Kitalong, H. Nabeyama, J. Emesiochel), Calophyllum inophyllum var. wakamatsui (btachesked) (T. Belchal), Terminalia catappa (C. Kitalong) and Campnosperma brevipetiolata (C. Kitalong).

Five species of trees are specifically used for making the hulls of canoes. Gmelina palawensis is used to make canoe sides or covers (Ucheldekes Rebluud). Lumnitzera littoralis wood is good for the canoe outriggers, with its curved branches straightened by heating (S. Ubedei). The sides, body and covering of canoes can be made from Gmelina palawensis (E. Rebluud). 
Table 6. Tree species most frequently mentioned by males for use in construction of structures.

\begin{tabular}{|c|c|c|c|c|}
\hline Species (Palauan name) & Use & $\begin{array}{l}\text { Males interviewed } \\
\quad(n=17)\end{array}$ & $\begin{array}{l}\text { Oikull } \\
(n=10)\end{array}$ & $\begin{array}{c}\text { Ibobang } \\
(n=7)\end{array}$ \\
\hline $\begin{array}{l}\text { Gmelina palawensis H.L. Lam var. palawensis } \\
\text { (blacheos) }\end{array}$ & Posts, flooring, walls & 8 & 4 & 4 \\
\hline Bambusa vulgaris Schrad. ex Wendl. (bambuu) & Flooring & 7 & 4 & 3 \\
\hline Lumnitzera littoralis (Jack) Voigt (mekekad) & $\begin{array}{l}\text { Main frame, posts, upper and } \\
\text { lower house }\end{array}$ & 7 & 2 & 5 \\
\hline Rhizophora mucronata Lam. (tebechel) & Frame of dock, beam & 6 & 2 & 4 \\
\hline Ceriops tagal (Perr.) C. B. Robinson (biut) & Frame & 5 & 2 & 3 \\
\hline Serianthes kanehirae Fosb. var. kanehirae (ukall) & Flooring & 4 & 4 & 0 \\
\hline Sonneratia alba J.E. Sm. (urur) & Frame of dock, posts & 4 & 2 & 2 \\
\hline Stemonorus ammui (Kaneh.) Sleumer (ngmui) & Posts, crossbeams, & 4 & 1 & 3 \\
\hline Intsia bijuga (Colebr.) 0. Kuntze (dort) & Frame, flooring & 2 & 2 & 0 \\
\hline Calophyllum pelewensis P.F. Stevens (chesemolech) & Main frame & 2 & 0 & 2 \\
\hline Total & & 49 & 23 & 26 \\
\hline
\end{tabular}

Table 7. Tree species most frequently mentioned by males to construct a canoe.

\begin{tabular}{|c|c|c|c|}
\hline Species (Palauan name) & $\begin{array}{l}\text { Males interviewed } \\
\qquad(n=17)\end{array}$ & $\begin{array}{c}\text { Oikull } \\
(n=10)\end{array}$ & $\begin{array}{c}\text { Ibobang } \\
\qquad(n=7)\end{array}$ \\
\hline Serianthes kanehirae Fosb. var. kanehirae (ukall) & 6 & 4 & 2 \\
\hline Calophyllum inophyllum L. (btaches) & 3 & 1 & 2 \\
\hline Calophyllum inophyllum L.var. wakamatsui (Kaneh.) Fosb. and Sach. (btachesked) & 3 & 1 & 2 \\
\hline Artocarpus atilis (Parkinson) Fosb. (meduu) & 2 & 1 & 1 \\
\hline Terminalia catappa L. (miich) & 2 & 1 & 1 \\
\hline Artocarpus mariannensis Trécul (chebiei) & 2 & 1 & 1 \\
\hline Campnosperma brevipetiolata Volk. (kelelacharm) & 1 & 1 & 0 \\
\hline Total & 19 & 10 & 9 \\
\hline
\end{tabular}

Trees used to make canoe paddles include Terminalia catappa, Campnosperma brevipetiolata, Syzygium samarangense, Hibiscus tiliaceus, Dolichandrone spathacea (rriu), Inocarpus fagifer, Swietenia mahogany (mahogani) and Cerbera manghas. Canoe sails (yars) are fashioned from woven Pandanus leaves.

\section{Cordage}

Rope is used in construction, to carry loads, to tie food packets and for numerous other everyday tasks. Rope is made from fibres (C. Kitalong) of the bark of Wikstroemia elliptica (tebudel), Hibiscus tiliaceus, Commersonia bartramia (chermalluang), Ambroma augustata (lab), Trichospermum ledermannii (chelsau) and the Cocos nucifera husk (E. Singeo). Fibres from the stems of Cyrtosperma merkusii and Musa textiles (blantalos) are used to wrap light loads (C. Kitalong, E. Ridep, M. Rehurer). The leaves of Draceana multiflora (orredakl) are used for general tying (K. Tesei), while the vine of Derris trifoliata (kemokem) is used to tie bamboo together for rafts (S. Ubedei) and to tie packages of food items (C. Kitalong). Canavalia 
cathartica (kldelleland) and Merremia peltata (kebeas) are used to tie light items (C. Kitalong), as is Nepenthes mirabilis (meliik) (D. Otobed).

\section{Firewood}

The best firewood is Maranthes corymbosa (bkau), although Rhizophora mucronata and $R$. apiculata (bngaol) are also good because they burn slowly (T. Belchal). Other trees used as firewood include Casuarina equisetifolia (ngas), Cocos nucifera, Rhus taitensis (eues), Pouteria obovata (chelangel), Alphitonia carolinensis (chelebiob) and Macaranga carolinensis. Excoecaria agallocha (ias) is used for firewood, but is also known to be poisonous to the eyes (V.R. Tadeo).

\section{Cleaning}

Many plants are used in personal hygiene, for cleaning the body, teeth, hair and clothes, and to produce a nice smell. Barringtonia racemosa (koranges) is used as soap (W. Metes, C. Kitalong). Ceratopteris thalictroides (tiela uek) produces suds and is used as shampoo (I. Ngiraibai). The Colubrina asiatica (derikel) stem is pounded until suds appear and is used both to wash clothes and as bathing soap (I. Ngiraibai). Limnophila aromatica (iaml) is used to wash after working in the taro patch (N. Kitalong, B.S. Chiokai). The tendril of Nepenthes mirabilis is used to clean teeth (M. Ngirametuker, C. Kitalong, E. Rebluud). Averrhoa bilimbi (imekurs) fruit is used to clean teeth, as well as boats, as it acts as a bleaching agent (C. Kitalong). The leaves of Cananga odorata (irang irang), Cymbopogon citratus and Melicope denhamii (kertub) produce a fragrant odour and are used to wipe the body (E. Rebluud). Macaranga carolinensis and fibres from Cocos nucifera are used as a natural tissue paper (C. Kitalong, T. Belchal, R. Bausouch, S. Yano).

Fishing

Fishing is a key activity for Palauan males, who practise such traditional fishing techniques as line fishing, netting, poisoning and spearing (Masse 1989; Johannes 1992). Fish are also caught in basket traps and fish weirs and propagated in fish ponds. Fishing techniques vary with the fish taxa being sought and the habitat being exploited.

Bamboo and wood basket traps $(b u b)$ are commonly used in Palau. Basket traps vary depending on the type of fish to be caught. Smaller basket traps like the kosekl and bub el dech are used in shallow water to catch small goatfish, sea bass, surgeonfish and wrasse. Larger traps such as the techioll and bub el komud are lowered into deeper water to catch bumphead parrotfish, humphead wrasse, large sea chup, sea bass, sharks and turtles. Fish traps (semael) are made with Bambusa vulgaris and lashed together with the Derris trifoliata vine, which is also used to tie bamboo rafts (S. Ubedei). Loeseneriella macrantha var. palauica (kerrangel) is also used to tie fish and crab traps (S. Ubedei, T. Belchal).

Traditionally, a large variety of fishing nets was used in Palau. As with baskets, the net and the mesh size varies according to the prey sought. Palauans created nets that could be operated by an individual, nets for a small fishing party, or extremely large nets (direkorek) necessitating a group. Some of the smaller, single-person nets include the derau a mekebu, derek, 'aikurs', kual a chemang, 'garn' (charm?), kual a ngoaol, mangidab and methilab. The bilokl, ruul and sab are some of the nets that can be operated by a single individual or a small group. Typically, net types are used for specific prey; for example, 'aikurs' nets are reported to catch sea bass, emperor and rabbitfish, while direkorek was used primarily for humphead wrasse, bumphead parrotfish, surgeonfish and rays.

Smaller nets were generally made from Cocos nucifera husk fibre (S. Ubedei). Larger fish nets (ruul) are made with Heterospathe elata var. palauensis leaves (H. Nabeyama), which are preferred over coconut leaves because they are stronger (S. Ubedei). The leaves are tied using 
either Derris trifoliata or Hibiscus tiliaceus (S. Ubedei). The frame for a small hand net (derau) is fashioned from Allophylus timoriensis (chebeludes) (R. Bausouch, S. Ubedei) and B. vulgaris (T. Belchal). Macaranga carolinensis is used to make light wooden floats for the net (S. Ubedei). The prop roots (raod) of the mangrove trees Rhizophora mucronata and $R$. apiculata are used to lure fish out of the rocks (H. Nabeyama) before they are caught by a net, spear or natural poison.

Spearing is a common Palauan fishing technique. Ethnographically, there were two main spear types, the klebiskang, with a single hardwood point, and the taod, with a cluster of barbed points. The klebiskang is used to catch taxa such as large species of parrotfish, triggerfish and wrasse, as well as rays and sharks. The taod is used on such fish as cornetfish, jacks and needlefish. Spears are made with Areca catechu (E. Singeo) and Schizostachyum lima (C. Kitalong, T. Belchal). Lumnitzera littoralis is used to make spear handles (S. Ubedei). Intsia bijuga is used for spear guns (C. Kitalong, V.R. Takeo).

Plants are not only employed to make fishing nets, traps and spears, but provide cues to signal the appropriate time to catch particular species. When Melastoma malabathricum var. mariannum (matakui) is in full bloom, sea urchins and clams are ripe and ready to be harvested (M. Ngirametuker). When Serianthes kanehirae are in full bloom, there will be many fish, especially during the high tide (R. Alii).

\section{Hunting}

Few terrestrial animals contributed significantly to the traditional diet. In the ethnohistorical records, terrestrial protein sources are limited to crabs, bats and birds, such as the duck and pigeon and the eggs of the Micronesian megapode (Megapodius laperouse senex) and the white tern (Gygis alba pacifica) (Kubary 1892). Archaeological evidence exists for the consumption of pigs as a status food (Sus scrofa), although they were apparently extirpated by the first substantial Western contact with the islands in 1783 (Masse et al. 2006). Today, men hunt for birds, bats and wild pigs and set traps for wild chickens and crabs.

Land traps (bedikl) are made with the flexible stem of Ixora casei (kerdeu) (S. Ubedei, T. Belchal, C. Kitalong, V.R. Takeo) and Cocos nucifera fibre (S. Ubedei). Once the chicken takes the bait, it trips the trap and is caught in the fibre snare as the stem springs backwards (C. Kitalong). Symplocos racemosa var. palawensis (chebtui) is used to make the slingshots used in bird and bat hunting (T. Belchal).

\section{Medicine}

The medicinal plants category contains the greatest number of species for a given task. Informants provided a medicinal use for 95 plant species. Oikull interviewees described 80 medicinal plant uses, with 41 provided by the men and 39 by the women. In Ibobang, 52 medicinal plant uses were described, with men and women each giving 26 uses. Frequently mentioned uses were pain relief from toothaches, earaches and headaches; cures for diarrheoa, bleeding and boils; and overall cleansing and healing (Table 8). Premna serratifolia (chosm) and Phaleria nisidai (ongael) were the two species most commonly referred to as providing a medicinal value.

Premna serratifolia is used to stop cuts from bleeding (C. Kitalong, M. Rehuher) - one young chewed leaf is applied to small cuts and the inner slimy bark to deeper cuts (F. Wasisang, J. Emesiochel, S. Obedei, V.R. Tadeo, M. Besebes, G. Emesiochel). The bark is peeled and drops of the clear inner sap are placed on stings or wounds caused by sea urchins or fish spines, to ease the pain. Another preparation method for P. serratifolia as a pain medication is to place the extracted sap into a spoon with hot coconut oil and put the infected area into the resultant steam or smoke (T. Belchal, R. Bausouch, S. Yano). Premna serratifolia also stops bleeding from 
Table 8. Most frequently mentioned medicinal plants.

\begin{tabular}{|c|c|c|c|c|}
\hline Species (Palauan name) & Use & $\begin{array}{l}\text { Total interviewed } \\
\qquad(n=43)\end{array}$ & $\begin{array}{c}\text { Oikull } \\
(n=27)\end{array}$ & $\begin{array}{l}\text { Ibobang } \\
(n=16)\end{array}$ \\
\hline Premna serratifolia L. (chosm) & $\begin{array}{l}\text { Cuts, weight loss, asthma, mosquito repellant, } \\
\text { pain reliever }\end{array}$ & 16 & 10 & 6 \\
\hline Phaleria nisidai Kaneh. (ongael) & $\begin{array}{l}\text { Cleansing, flushing, build immunity, aches and } \\
\text { pain, heart ailment, diarrheoa and abortion }\end{array}$ & 15 & 6 & 9 \\
\hline Morinda citrifolia L. (ngel) & Cuts, weight loss and boils & 9 & 6 & 3 \\
\hline Curcuma longa L. (kesol) & Medicinal ointment for skin and stretch marks & 9 & 6 & 3 \\
\hline Cocos nucifera L. (lius) & $\begin{array}{l}\text { Cleansing, earache, external ointment } \\
\text { strengthening immune system, boils, diarrhea }\end{array}$ & 8 & 3 & 5 \\
\hline $\begin{array}{l}\text { Syzygium samarangense (Blume) } \\
\text { Merr. and Perry (rebotel) }\end{array}$ & $\begin{array}{l}\text { Cuts, sore throats, colds stretch marks, herbal } \\
\text { bath, external rash or itch }\end{array}$ & 7 & 5 & 2 \\
\hline Millettia pinnata Panigrahi (kisaks) & Use in herbal bath after first born & 6 & 2 & 4 \\
\hline Calophyllum inophyllum L. (btaches) & Asthma, strength & 5 & 3 & 2 \\
\hline $\begin{array}{l}\text { Epipremnum carolinense Volk. } \\
\text { (toilalech) }\end{array}$ & Menstruation, abortion & 5 & 5 & 0 \\
\hline $\begin{array}{l}\text { Barringtonia racemosa (L.) Spreng. } \\
\text { (koranges) }\end{array}$ & Heartburn, stop bleeding, abortion & 4 & 4 & 0 \\
\hline Casuarina equisetifolia L. (ngas) & Toothaches, abortion & 4 & 3 & 1 \\
\hline Total & & 88 & 53 & 35 \\
\hline
\end{tabular}

head injuries (R. Alii, C. Kitalong) and is used in combination with other plants for weight loss (O. Belaio). The leaves are mashed and placed on the body to act as a mosquito repellant $(\mathrm{H}$. Yuri). Four leaves of P. serratifolia and four leaves of Codiaeum variegatum (kesuk ianged) are boiled for one minute and drunk as tea to treat asthma (E. Rebluud).

Phaleria nisidai heals many illnesses and is used in combination with other plants for bodily cleansing and flushing (C. Kitalong, M. Ngirametuker, T. Watanabe, N. Kitalong). Its leaves are boiled into a tea drunk in specific amounts to build immunity and relieve aches in the stomach (M. Ngirametuker) and body (H. Nabeyama, G. Emesiochel). Phaleria nisidai is used for headaches, menstruation pain and to strengthen the body (M. Rehurer, F. Wasisang, M. Besebes). The plant acts as an energiser (B.S. Choikai) and is used for heart ailments (I. Spesungel). Combined with Psidium guajava (kuabang) leaves, P. nisidai is a remedy for diarrheoa (M. Besebes). It is also one of the plants used during the first birth ritual and ceremony (F. Wasisang).

As part of the Modekngei religious ritual, its members gather on special dates to worship and share a herbal drink that cleanses the body. Some of the plant species in this drink are Dianella carolinensis (kebesos), Phaleria nisidai, Melastoma malabathricum L. var. mariannum, Nepenthes mirabilis, Lycopodiella cernua (olechuila beab) Dicranopteris linearis var. ferruginea (itouch), Cassytha filiformis (tellelachull), Trema cannabina Lour. (chelodechoel) and Hedyotis korrorensis (chemudalech) (M. Ngirametuker).

\section{Two keystone plants}

The elders provided 39 separate uses for Cocos nucifera, making it the study's most useful plant species (Table 9). Due to its importance, as reflected in the number of different uses, C. nucifera is a 'cultural keystone species' (Garabaldi and Turner 2004) in many Pacific Island nations 
Table 9. Most frequently mentioned trees with a specific use.

\begin{tabular}{|c|c|c|c|}
\hline Species (Palauan name) & $\begin{array}{l}\text { Total interviewed } \\
\qquad(n=43)\end{array}$ & $\begin{array}{c}\text { Oikull } \\
(n=27)\end{array}$ & $\begin{array}{c}\text { Ibobang } \\
(n=16)\end{array}$ \\
\hline Cocos nucifera L. (lius) & 67 & 39 & 26 \\
\hline Areca catechu L. (buuch) & 19 & 15 & 9 \\
\hline Premna serratifolia L. (chosm) & 13 & 5 & 8 \\
\hline Syzygium samarangense (Blume) Merr. and Perry (rebotel) & 11 & 11 & 0 \\
\hline Macaranga carolinensis Volk. (bedel) & 11 & 7 & 4 \\
\hline Rhizophora spp. (tebechel and bngaol) & 9 & 6 & 7 \\
\hline Spondias pinnata (titimel) & 9 & 7 & 3 \\
\hline Calophyllum inophyllum L. (btaches) & 8 & 6 & 5 \\
\hline Averrhoa bilimbi L. (imekurs) & 8 & 8 & 1 \\
\hline Melastoma malabathricum L. var. mariannum (Naudin) Fosb. and Sach. (matakui) & 8 & 6 & 3 \\
\hline Terminalia catappa L. (miich) & 7 & 3 & 4 \\
\hline Ixora casei Hance (kerdeu) & 7 & 2 & 6 \\
\hline Total & 177 & 112 & 76 \\
\hline
\end{tabular}

(e.g. Samoa, Whistler 1996) and in Central and South America (e.g. Belize, Arvigo and Balick 1998). Ridep Emesiochel calls the coconut tree the 'mother of Belau' because of its many uses. The recorded uses of coconut are similar in Oikull and Ibobang, with multiple interviewees providing similar uses. With 19 documented uses, Areca catechu is the second most identified plant in the study and is another cultural keystone species.

Clarence Kitalong listed 24 uses for the nut $(n=7)$, trunk $(n=8)$ and leaves $(n=9)$ of the coconut palm. The coconut meat (endocarp) is a food and the fluid a drink. The hard outer nut (exocarp) is used for cups, bowls and utensils. Coconut oil is used singly or as one of several ingredients in food and medicine, to protect the skin after bathing from bites, infection or skin diseases, as a hair conditioner and as a mosquito repellent. The exocarp fibres start fires and keep them burning hot, and are fashioned into sieves and rope. The trunk of the coconut palm is used as firewood and to make trap doors, stirring utensils, taro-pounding implements, tool handles, walking canes, spears, benches and wall and flooring material. Coconut leaves are woven into baskets (Figure 3), folded as wraps for fish and ground tapioca, used as torches to provide light and made into ropes and toys such as balls, canoes and windmills. The midrib of the frond is used to make brooms and catch shrimp.

Fourteen uses for the coconut leaves $(n=4)$, nut $(n=9)$ and trunk $(n=1)$ were provided by T. Watanabe, including its use as an ingredient in herbal hot baths, as food, and to make ropes, handbags, hats, brooms, water dippers, buttons, bras, belts, hair picks, baskets, hair oil and sieves. Dirratkelkang M. Ngirametuker provided 13 uses for the coconut leaves (baskets, brooms, firewood and toys), the branches (toys), the trunk (implements, canes and construction material), and the nut and its fibres (sieve, rope, oil, food and syrup).

Dirratesei E. Singeo described other uses of coconut, including the exocarp being used as a lime holder for the preparation of betel nut, and the nut's oil being rubbed on the stomach to ease stomach aches. Because the healthy coconut juice cleanses the intestines, babies, young children and elders drink it to strengthen their immune systems. The young soft meat is sweet and good for desserts or snacking. After the nut is mature and the meat is hard, it is tasty when eaten with Cyrtosperma merkusii. Grated coconut meat is placed in a white cloth and wrung to 


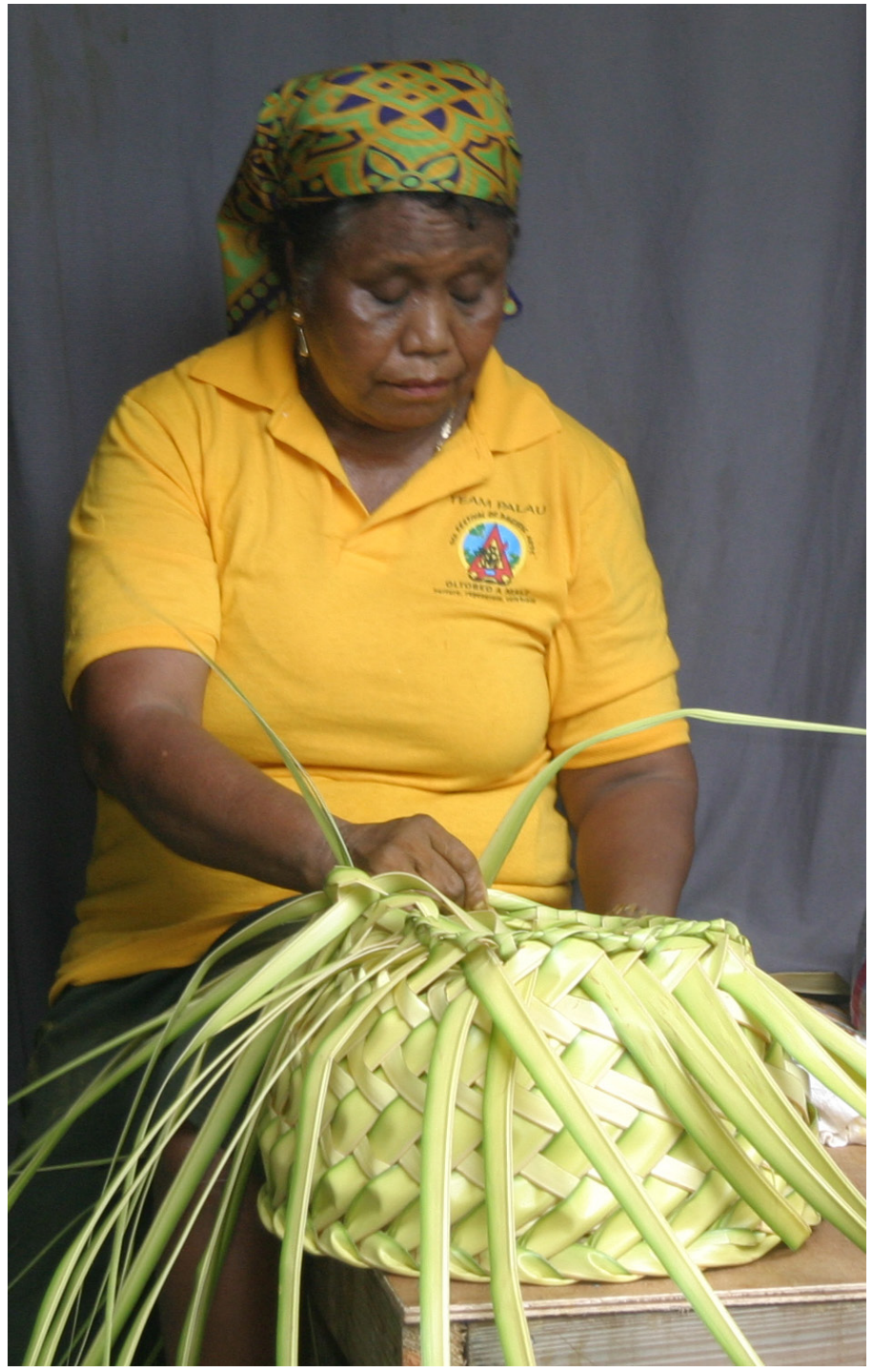

Figure 3. Dirrngerchemuul (Hinako Ngirmekur) weaving a terkill (a basket used to carry food for travelling) from Cocos nucifera (lius).

extract the milk used in food preparation and to revitalise hair by making it shiny, silky and strong. The grated meat can also be placed in a coconut sheath and heated and the warm oil used to heal a wound cleaned with Morinda citrifolia (ngel) (C. Kitalong). Coconut fronds are cut off the main midrib and stripped to leave the rachis, which is gathered and tied to make a broom. Individual pieces of the rachis are used to catch shrimp and small lizards. The young fronds can be woven to make small balls and animals to entertain children. Benches and flooring are constructed from the trunk.

After childbirth, the male or female placenta is wrapped in coconut fronds to symbolise manhood or womanhood and prosperity (W. Metes, C. Kitalong). The young frond is a symbol used during the passing of a chiefly title (E. Singeo, H. Takeo, N. Luii, M. Kim, A. Bintorio). Dirrngerchemuul $\mathrm{H}$. Takeo demonstrated how the young coconut leaf is prepared with the wild taro leaf to symbolise the transfer of clan titles. While the ritual to transfer traditional titles is practised or performed by men, it is the women who are the recipients of the title symbolised by the coconut and wild taro leaf.

The process of making rope from coconut husk fibres was described by Dirratesei E. Singeo. After the husks are buried under the sand in the ocean for about a month, they are pounded to remove excess fluid and stray fragments, rinsed with water and left to dry. Once dried, the fibres are placed in one's lap to be rolled in a circular motion and elongated by connecting one end to 
another. It takes many coconut husks to make a single rope. One basket full of fibres from the coconut husk can make about $7 \mathrm{~m}$ of thick rope used for constructing a house or $12 \mathrm{~m}$ of thin rope to make tools (C. Kitalong). This rope can be used in tying together parts for traditional canoes, tools and structures such as a men's meeting house.

The coconut endocarp is used as food and drink, the fibres from the husk are used to make rope and to embellish fish hooks, the husk is firewood, the meat is ground for milk and oil that is used to remove skin boils and water from the ear, and the leaves are used to wrap food. Coconut fibre is used to make small hand nets (derau) and land traps for crabs and chickens (S. Ubedei) and to wrap food and cleanse the body (I. Ngiraibai). The leaves are woven into toys (btul or eberdord), the nut's oil is used for ear aches and the husk is used to make smoke (F. Wasisang). The leaves can be made into brooms, baskets and food wrapping; the nut is a source of food and drink; the trunk is used for firewood and to make small bridges and benches; the meat from young coconuts $(k l e u)$ is mixed with salt and eaten to prevent dehydration, the young sprout (meolt) is used to wrap tapioca and make grass skirts (G. Emesiochel, S. Chiokai). The husk (ulengchidel) is used to clean pots and make rope or cords, and the trunk is used for compost and flooring (S. Chiokai).

Nineteen uses for Areca catechu were given by women from Oikull (E. Singeo, M. Kim, N. Luii, H. Takeo). The nut is chewed with lime and Piper betle (kebui) leaf as a stimulant. The Areca catechu nut and Piper betle leaves are an integral part of customary exchanges between clans during important rituals such as first-birth, marriage and funerals. The Areca catechu palm has numerous medicinal purposes. The root is used with Leea guineensis (sngall) to ease menstrual cramps, and in Ibobang, is one of the plants in the ritual cleansing after the first menstruation (F. Wasisang). Juice from the pounded roots relieves toothaches. Five to seven days after the umbilical cord has fallen off, betel-nut juice is applied to a newborn's navel as a natural antiseptic. Heating the ripe nut softens it so that juices can be extracted and applied mornings and evenings after the newborn's bath. To prevent bed wetting, the nut is cut in half and given to babies to chew and suck on.

The betel-nut trunk is cut into flooring and benches (G. Emesiochel). The lower portion of the trunk is used to make spears, dancing paddles and sticks. Areca catechu leaves are used for fertiliser. Its smooth inner sheath is good for long-term food storage (up to a week, depending on the type of food), to wrap a baby and as a raincoat. Sheaths are fashioned into dancing skirts and, when sewn together with Hibiscus tiliaceous fibre, used to make coats and handbags. The outer sheath is stripped and pounded to make a loincloth. Infants bite down on the young fronds when teething. Children play by sitting inside the fronds and sliding down hills (F. Wasisang).

\section{Conclusion}

During 2006 to 2010, an ethnobotanical study was conducted in Oikull, Airai State, and Ibobang, Ngatpang State, on Babeldaob, Palau's largest island. The objective of this pilot study was to document in as much detail as possible the use of plants in all aspects of Palauan culture, using the theme 'the cycle of life', or from birth to death. During interviews, we recorded uses for 200 plant species; 171 species in Oikull and 127 in Ibobang. Plants were mainly used for medicine (70 species), construction ( 41 species), food (27 species) and toys (22 species). Knowledge differed depending on traditional gender roles and practices. Men described plants used for construction, tool making, firewood, fishing and canoe making. Women described plants used for medicinal uses for the first-birth ceremony (Figure 4). Men and women described how 


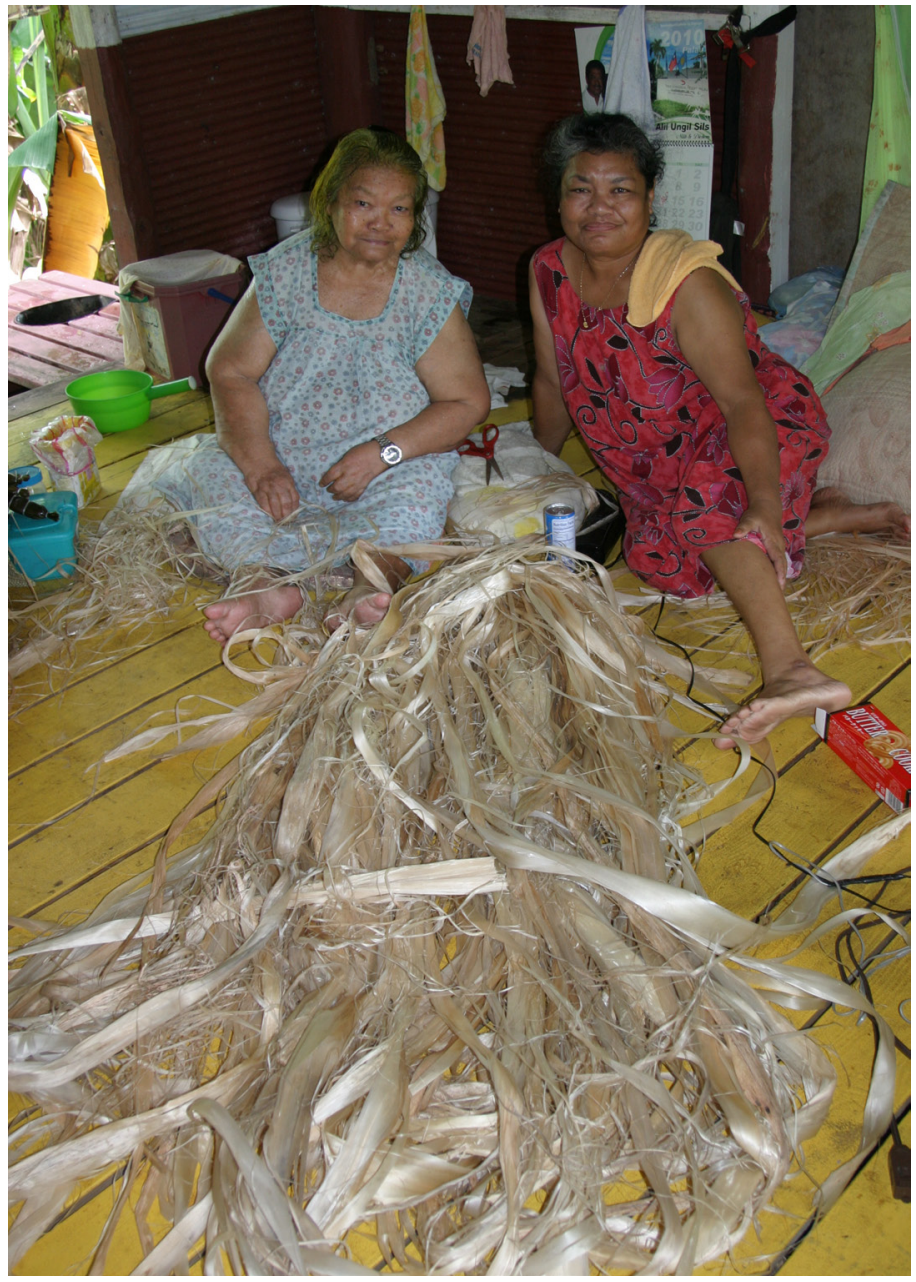

Figure 4. Uodelchad ra Esel (Terue Daniel) and her daughter Uwai Skebong sorting the inner bark fibres of Hibiscus tiliceaus (chermall) in preparation for making a grass skirt for a first-birth ceremony.

plants were used for food, recreation, art and medicine for primary care. Two palm species, Cocos nucifera and Areca catechu, had the most uses and were considered cultural keystone species.

This preliminary study shows that Ibobang and Oikull use many plant species for similar purposes. The communities continue to maintain strong ties between their plants and culture. We found that there are certain families or individuals who are renowned for their knowledge and have very specific skills that are part of their own family knowledge and a source of prestige and wealth. There is much more knowledge that needs to be documented in Palau. This is only the beginning. We were heartened by a summer youth program in Ibobang where we observed and documented the elders teaching their youth how to build crab traps, weave baskets, fish and fix Palauan food. Oikull's traditional leaders have also begun youth programs.

Conservation of plant diversity, integration of traditional knowledge and practices in educational programs, and promotion of culture thorough local, regional and international fairs will ensure that the Palauan culture and its plant diversity survives through the next millennium. 


\section{Acknowledgements}

This paper results from a multidisciplinary field project studying the relationship between plants and people in Palau, and in the larger context, throughout Micronesia. This effort is focusing on botany, ethnomedicine, traditional land management and resource systems, conservation and education. We are grateful to the The V. Kann Rasmussen Foundation, Edward P. Bass and the Philecology Trust, the Marisla Foundation, the MetLife Foundation, the Germeshausen Foundation and the National Geographic Society Committee for Research and Exploration. We thank the people of Oikull and Ibobang and the Board of Trustees of the Belau National Museum for their support, guidance and participation in this project.

\section{Note}

1. Sharks were hunted from sail boats with special hooks. Mlamitoi from Peleliu who grew up in Oikull's Ngesileong clan was known for trapping a shark by himself. He could both manoeuvre the sail of his canoe and catch the shark by throwing a coconut to it to bite on (A. Rufino). There is a legend in Oikull of how an Airai god, Medechii, claimed Ngerduais Island. Medechii challenged the other gods that whomever could throw the betel nut fiber (ulemachel) the furthest would own Ngerduais Island. While the gods were fixing their betel nut, chewing it and preparing to throw, Medechii put the red honeyeater bird (chesisebangiau) into his mouth pretending it was his betel nut as it was red like a chewed betel nut. The gods threw their betel nut and Medechii grabbed the bird out of his mouth quickly without being detected. The bird flew all the way to Ngerduais and Medechii claimed the island as his own. 


\section{References}

Arvigo, R. and Balick, M. 1998. Rainforest Remedies. Lotus Press, Twin Lakes, Wisconsin.

Athens, J.S. and Ward, J.V. 2001. Paleoenvironmental evidence for early human settlement in Palau:

The Ngerchau core. In: Stevenson, C.M. and Morin, F.J. (eds), Proceedings on the fifth international conference on Easter Island and the Pacific, pp. 165-178. Easter Island Foundation, Los Osos.

Athens, J.S. and Ward, J.V. 2002. Holocene paleoenvironmental investigations on Ngerekebesang, Koror, South Babeldaob, and Peleliu Islands, Palau. Report prepared for Palau National Communications Corporation, Republic of Palau. International Archaeological Research Institute, Inc., Honolulu.

Athens, J.S. and Ward, J.V. 2005. Palau Compact Road archaeological investigations, Babeldaob Island, Republic of Palau; Volume IV: Holocene paleoenvironment and landscape change. Report prepared for the Department of the Army, U.S. Army Engineer District, Honolulu. International Archaeological Research Institute, Inc., Honolulu.

Balick, M.J. (ed), 2009. Ethnobotany of Pohnpei: Plants, people, and island culture. University of Hawai' $\mathrm{i}$ Press/The New York Botanical Garden, Honolulu.

Balick, M.J. and Cox, P.A. 2005. Plants, people, and culture. The science of ethnobotany. Scientific American Press, New York.

Black, P.W. 1968. Notes on medicinal plants of Tobi. Unpublished manuscript on file at the Palau Bureau of Arts and Culture, Koror, Palau.

Canfield, J., Herbst, D. and Stemmerman, L. 1992. Rapid ecological assessment of areas in Palau considered for conservation: Ngeremeduu Bay drainage area (Draft). Report prepared for U.S. Fish and Wildlife Service, Pacific Islands Office.

Cole, T.G., Falanruw, M.C., MacLean, C.D., Whitesell, C. and Ambacher, A.M. 1987. Vegetation survey of the Republic of Palau. Resource Bulletin PSW-22. Pacific Southwest Costion, C. and Kitalong, A. 2006. Babeldaob forest survey. Belau National Museum and The Nature Conservancy, Palau Field Office, Koror, Republic of Palau.

Forest and Range Experiment Station, U.S. Forest Service, U.S. Department of Agriculture, University of California Press, Berkeley.

Defilipps, R.A., Marina, S.L. and Pray, L.A. 1988. The Palauan and Yap medicinal plants - Studies of Masyoshi Okabe, 1941-1943. Atoll Research Bulletin No. 317. National Museum of Natural History, Smithsonian Institution, Washington D.C.

Del Rosario, A.G. and Esquerra, N.M. 2003. Medicinal plants in Palau, Volume 1. PCC-CRE Publication 28/03 (3.0C).

Donnegan, J.A., Butler, S.L., Kuegler, O., Stroud, B.J., Hiserote, B.A. and Rengulbai, K. 2007. Palau's forest resources, 2003. Resource Bulletin PNW-RB-252. U.S. Department of Agriculture, Forest Service, Pacific Northwest Research Station, Portland, Oregon.

Farnsworth, N., Akerele, A.O., Bingel, A.S., Soerjarto, D.D. and Guo, Z. 1985. Medicinal plants in therapy. Bulletin of the World Health Organization 63:965-981.

Fosberg, F.R. 1946. Botanical report on Micronesia. U.S. Commercial Company Economic Survey of Micronesia 13(1).

Fosberg, F.R. 1947. Micronesian mangroves. Journal of the New York Botanical Garden 48: 128-148.

Fosberg, F.R. 1957. Vegetation of the oceanic province of the Pacific. In: Proceedings of the VIII Pacific Science Congress (Quezon City 1953) 4:48-55.

Fosberg, F.R. 1960. The vegetation of Micronesia. I. General descriptions, the vegetation of the Marianas Islands, and a detailed consideration of the vegetation of Guam. Bulletin of the American Museum of Natural History 119:1-75

Fosberg, F.R. and Sachet, M.H. 1975a. Flora of Micronesia, 1: Gymnospermae. Smithsonian Contributions to Botany 20:1-15.

Fosberg, F.R. and Sachet, M.H. 1975b. Flora of Micronesia, 2: Casuarinaceae, Piperaceae, and Myricaceae. Smithsonian Contributions to Botany 24:1-28. 
Fosberg, F.R. and Sachet, M.H. 1977. Flora of Micronesia, 3: Convolvulaceae. Smithsonian Contributions to Botany 36:1-33.

Fosberg, F.R. and Sachet, M.H. 1979. Maesa (Myrsinaceae) in Micronesia. Phytologia 44 (1):363-369.

Fosberg, F.R. and Sachet, M.H. 1980a. Flora of Micronesia, 4: Caprifoliaceae-Compositae. Smithsonian Contributions to Botany 46:1-71.

Fosberg, F.R. and Sachet, M.H. 1980b. Systematic studies of Micronesian plants. Smithsonian Contributions to Botany 45:1-44.

Fosberg, F.R. and Sachet, M.H. 1981. Nomenclatural notes on Micronesian ferns. American Fern Journal 71(3):82-84.

Fosberg, F.R. and Sachet, M.H. 1984. Micronesian Poaceae: Critical and distributional notes. Botany Department, Smithsonian Institution, Washington, D.C.

Fosberg, F.R. and Sachet, M.H. 1987. The Genus Timonius (Rubiaceae) in the Palau Islands. Micronesica 20(1-2):157-164.

Fosberg, F.R. and Sachet, M.H. 1991. Studies in Indo-Pacific Rubiaceae. Allertonia 6(3):191-278.

Fosberg, F.R. and Raulerson, L. 1990. New and noteworthy Micronesian plants. Micronesica 23(2):150.

Fosberg, F.R., Sachet, M.H. and Oliver, R.L. 1979. A geographical checklist of the Micronesian Dicotyledonae. Botany Department, Smithsonian Institution, Washington, D.C. Micronesica 15(1-2):41-298.

Fosberg, F.R., Sachet, M.H. and Oliver, R.L. 1982. A geographical checklist of the Micronesian pteridophytes and gymnosperms. Botany Department, Smithsonian Institution, Washington, D.C. Micronesica 18(1):23-82.

Fosberg, F.R., Sachet, M.H. and Oliver, R.L. 1987. A geographical checklist of the Micronesian Monocotyledoneae. Botany Department, Smithsonian Institution, Washington, D.C. Micronesica 20(1-2):19-129.

Fosberg, F.R., Sachet, M.H. and Oliver, R.L. 1993. Flora of Micronesia, 5: Bignoniaceae-Rubiaceae. Smithsonian Contributions to Botany 81:1-135.

Fosberg, F.R., Otobed, D., Sachet, M.H., Oliver, R.L., Powell, D.A. and Canfield, J.E. 1980. Vascular plants of Palau with vernacular names. Department of Botany, Smithsonian Institution, Washington, D.C.

Friend, N. and Tabak, N. 1995. Medicinal plants of Ngaraard. Center for Island Management Studies, School for Field Studies, Ngaraard State, Republic of Palau.

Garabaldi, A. and Turner, N. 2004. Cultural keystone species: Implications for ecological conservation and restoration. Ecology and Society 9(3): 1. URL: http://www.ecologyandsociety.org/vol9/iss3/art1

Hillmann Kitalong, A. and Holm, T. 2004. Forest habitat assessment project. Report prepared for the Palau Conservation Society, Koror, Palau.

Hillmann Kitalong, A. 2008. Forests of Palau: A long term perspective. Micronesica 40(1/2):9-31.

Hillmann Kitalong, A., DeMeo, R.A. and Holm, T. 2009. Native trees of Palau. The Environment, Inc, Koror, Palau.

Johannes, R.E. 1981. Words of the lagoon: Fishing and marine lore in the Palau district of Micronesia. University of California Press, Berkeley.

Jones, V. 1941. The nature and scope of ethnobotany. Chronica Botany 6(10):219-221.

Kanehira, R. 1933. Flora of Micronesica, Book I: General sketch of the flora of Micronesia. South Seas Bureau under Japanese Mandate. Translated by the Office of the Engineer, U.S. Army Pacific, Tokyo, Japan 1958.

Kapoor, L.D. 1990. CRC handbook on ayurvedic medicinal plants. CRV Press, Boca Raton.

Kitalong, C. 2007. Hepatoprotective and HCV-protease inhibitory activity of Palauan medicinal plants. Unpublished MA thesis, Toyama University.

Krämer, A. 1917, 1919 and 1929. Palau. In: Ergebnisse der Südsee-Expedition:1908-1910. Teilbands 1-4. Hamburg: L. Friederichsen and Co.

Kubary, J.S. 1892. Ethnographical material for the knowledge of the Caroline Archipelago. In: Volume 
II: Industry of Palau, pp. 117-219. Verlag Von P.W.M. Trap, Leiden.

Lee, R., Balick, M., Ling, D., Sohl, F., Brosi, B. and Raynor, W. 2001. Cultural dynamism and change - An example from the Federated States of Micronesia. Economic Botany 55(1):9-13.

Lee, R. 2009. Traditional medicine, Pohnpei and its integration. In: Balick, M. (ed), Ethnobotany of Pohnpei: Plants, people, and island culture, pp. 204-216. University of Hawaii i Press, Honolulu.

Liston, J. 2009. Cultural chronology of earthworks in Palau, western Micronesia. Archaeology in Oceania 44:56-73.

Liston, J. and Tuggle, H.D. 2006. Prehistoric warfare in Palau. In: Arkush, E. and Allen, M.W. (eds), pp. 148-193. The archaeology of warfare: Prehistories of raiding and conquest. University Press of Florida, Gainesville.

Machiko A. 2002. Modekngei: A new religion in Belau, Micronesia. Shinsensha Press, Tokyo Japan.

Masse, W.B. 1989. The archaeology and ecology of fishing in the Belau Islands, Micronesia. Unpublished $\mathrm{PhD}$ thesis, Southern Illinois University.

Masse, W.B., Liston, J., Carucci, J. and Athens, J.S. 2006. Evaluating the effects of climate change on environment, resource depletion, and culture in the Palau Islands between AD 1200 and 1600. Quaternary International 151(1):106-132.

Mayo, H.M. 1954. Report on the plant relocation survey and agricultural history of the Palau Islands. Office of the Forestry Conservation. Trust Territory of the Pacific Islands, Saipan.

Mukherjee, P.K. and Wahile, A. 2006. Integrated approaches towards drug development from Ayurveda and other Indian systems of medicines. Journal of Ethnopharmacology 103:25-35.

Okabe, M. 1941. Folk medicine of the Palau islander. Journal of the Anthropological Society of Nippon 56:413-426. Translated by H. Takeda for the Military Geology Branch, U.S. Geological Survey for Intelligence Division, Office of the Engineer Headquarters, Far East Commander, Tokyo, Japan.

Palau Society of Historians 2000. Medicine and therapy. Traditional and customary practices. English Series 6. Division of Cultural Affairs, Republic of Palau.

Palau Society of Historians 2001. Traditional items and properties of a household, clan, and village. English Series 7. Division of Cultural Affairs, Republic of Palau.

Palau National Environmental Protection Council 2004. Republic of Palau national biodiversity strategy and action plan. Report prepared for the Office of Environmental Response and Coordination, Republic of Palau.

Raulerson, L., Rinehart, A.F., Falanruw, M.S., Singeo, Y., Slappy, S. and Victor, S. 1997. A botanical reconnaissance of the proposed Compact Road alignment on Babeldaob Island, Republic of Palau. Report prepared for Wil Chee Planning, Honolulu. University of Guam Herbarium (GUAM) Contribution No 32.

Salsedo, C.A. 1970. The search for medicinal plants of Micronesia. Micronesian Reporter. Third Quarter. pp. 10-17.

Salsedo, C.A. and Smith, D.G. 1987. Medicinal plants of Palau. Phytologia 64(1):63-77.

Stemmermann, L. 1981. A guide to Pacific wetland plants. Report prepared for the Department of the Army, U.S. Army Engineer District, Honolulu.

Telmetang, M. 1993. Bai. Imuul Series No. 1, Belau National Museum, Inc., Republic of Palau. Whistler, A. 1992. Tongan herbal medicine. Isle Botanica Press, Honolulu.

Whistler, A. 1996. Samoan herbal medicine. Isle Botanica Press, Honolulu. 
84 Kitalong, Balick, Rehuher, Besebes, Hanser, Soaladaob, Ngirchobong, Wasisang, Law, Lee, Tadeo, Kitalong and Kitalong

Appendix 1. Use categories with the total number of plant species for each village.

\begin{tabular}{|c|c|c|}
\hline Use & Oikull & Ibobang \\
\hline Medicine & 48 & 39 \\
\hline Food & 23 & 7 \\
\hline Construction & 14 & 43 \\
\hline Toys & 12 & 10 \\
\hline Fishing & 7 & 9 \\
\hline Cleaning & 6 & 2 \\
\hline Rope & 6 & 3 \\
\hline Canoe & 4 & 10 \\
\hline Farming & 4 & 5 \\
\hline Accessories & 3 & 0 \\
\hline Baskets & 2 & 1 \\
\hline Canoe paddle & 2 & 0 \\
\hline Clothing & 2 & 0 \\
\hline Custom & 2 & 1 \\
\hline Firewood & 2 & 10 \\
\hline Tools & 2 & 7 \\
\hline Chicken trap & 1 & 3 \\
\hline Decoration & 1 & 3 \\
\hline Dye & 1 & 3 \\
\hline Fibre & 1 & 0 \\
\hline Food wrap & 1 & 1 \\
\hline Magic & 1 & 0 \\
\hline Pillow & 1 & 1 \\
\hline Storyboard & 1 & 1 \\
\hline Bridge & 0 & 1 \\
\hline Chewing & 0 & 3 \\
\hline Sail & 0 & 2 \\
\hline Taboo food & 0 & 1 \\
\hline Total & 147 & 166 \\
\hline
\end{tabular}

